\title{
Computer program for distance learning of pesticide application technology
}

\author{
BRUNO MAIA and JOÃO P.A.R. CUNHA \\ Instituto de Ciências Agrárias, Universidade Federal de Uberlândia, \\ Caixa Postal 593, Campus Umuarama, 38400-902 Uberlândia, MG, Brasil \\ Manuscript received on December 21, 2009; accepted for publication on September 14, 2010
}

\begin{abstract}
Distance learning presents great potential for mitigating field problems on pesticide application technology. Thus, due to the lack of teaching material about pesticide spraying technology in the Portuguese language and the increasing availability of distance learning, this study developed and evaluated a computer program for distance learning about the theory of pesticide spraying technology using the tools of information technology. The modules comprising the course, named Pulverizar, were: (1) Basic concepts, (2) Factors that affect application, (3) Equipments, (4) Spraying nozzles, (5) Sprayer calibration, (6) Aerial application, (7) Chemigation, (8) Physical-chemical properties, (9) Formulations, (10) Adjuvants, (11) Water quality, and (12) Adequate use of pesticides. The program was made available to the public on July $1^{\text {st }}, 2008$, hosted at the web site www.pulverizar.iciag.ufu.br, and was simple, robust and practical on the complementation of traditional teaching for the education of professionals in Agricultural Sciences. Mastering pesticide spraying technology by people involved in agricultural production can be facilitated by the program Pulverizar, which was well accepted in its initial evaluation.
\end{abstract}

Key words: e-learning, pesticide application, spraying, teaching/learning strategies.

\section{INTRODUCTION}

The use of pesticides with the purpose of protecting plants is fundamental in guaranteeing productivity in agriculture. However, identifying the problem alone is not enough, no matter it regards weeds, phytopathogens or insects. It is necessary to determine which agrochemical should be used and at which amount it should be applied. The success of the application is determined by time and manner of doing it (Scudeler et al. 2004, Cho et al. 2008).

Besides knowing the product to be applied, its formulation, action mechanisms and physical-chemical characteristics, it is also necessary to dominate how to apply it properly in order to guarantee that the product reaches the target in an efficient way and thus minimizing losses (Cunha 2008).

Correspondence to: João Paulo Arantes Rodrigues da Cunha E-mail: jpcunha@iciag.ufu.br
The application of pesticides in an incorrect manner may cause damages to human health and the environment (Gil and Sinfort 2005). Even if these damages do not occur, mistakes during the application can reduce the effectiveness of a product in the pest control, causing economical loss or need for reapplication. So, if the treatment is effective, the product applied must reach its target (Kutcher and Wolf 2006).

However, when analyzing the training of professionals involved in Agrarian Sciences, more specifically those who are directly responsible for the applications carried out on the agriculture, it is noticed that these same people, in general, have a precarious understanding on the subject. So, one has to look for alternatives that minimize the problem, and one of these alternatives is distance learning.

According to Ghedine et al. (2006), growth in distance learning courses is being driven by several fac- 
tors, such as the high cost of traditional education and the speed at which changes occur in course content in a dynamic and personalized way. Temporary restrictions dictated by work schedules and travel difficulties, the growing importance of continuous learning, the geographical constraints that hamper potential students to travel, and the evolution of interactive technologies in communication also contribute to the adoption of distance teaching.

According to Almeida (2003), e-Learning developed from the needs of companies regarding their employees' training. The term e-Learning is the result of a combination between teaching with the aid of technology and distance learning. Both models came together for the purpose of on-line education and training based on computer networks, which resulted in e-Learning. To ensure the successful operation of distance education systems, computer facilities and network infrastructures must be integrated with appropriate software systems (Kim and Shih 2003). Thus, projects on building virtual environments to support teaching and learning were created, such as the Moodle, a free open source software package designed to help educators to create online courses (but it is not a very friendly software).

The PHP language, which resulted from the shortening of Hypertext Preprocessor, is an interpreted programming language that can be mixed within the HTML (Hypertext Markup Language) code, allowing a possible wide use especially in which concerns the development of programs for the world computer network. The set of orders and answers received and executed by the programming language and the database manager, as well as the way the information is presented, in a pleasant way and in hypertext form (HTML), are the necessary elements in the composition of virtual training in any area of knowledge.

However, the e-Learning also presents problems and should never be separated from practical knowledge. Reeves (2008) discusses these issues. The author shows that information technology extends educational opportunities to otherwise disenfranchised learners, but does not enhance the quality of instruction. One plausible reason is the lack of sufficient investment in evaluation strategies when information technology tools are being developed in educational contexts.
In this way, due to the shortage of instructional material in the area regarding technology for agrochemical application and the high growth in distance education, the aim of this work was to develop and evaluate a computer program for the distance learning of the theoretical part of the pesticide application technology by using tools of information technology.

\section{MATERIALS AND METHODS}

E-learning system in pesticide application technology, named as Pulverizar, was set up using the PHP programming language and MySQL database. Resources were added by means of Javascript, which is also a programming language, but works alongside the customer, in other words, on the user's browser.

The program was developed from January to July, 2008, in the premises of the Institute for Agrarian Sciences of the Federal University of Uberlândia (Brazil), and was evaluated during August and September, 2008. In a general way, it aims at helping students and professionals of Agrarian Sciences to get to know the principles for the application technology, seeking correct handling, selection and development of the techniques and equipments of the application of pesticides.

Initially, the student fills out a register with the following data: name, ID, education, login, password, e-mail, sex, age, city and state. All data are stored in the system database. When the user enters in the system with his/her identification, the date and time of entry are registered and, when finishing the session, the user should click in the "Log out" link, so that one knows how long the student was registered in the system and how many times he needed to enter it to conclude the course.

First of all, so as to elaborate the system, a visual setting of the course was made. It was idealized starting from two frames, the one on the left containing the identification of the Federal University of Uberlândia, authors and control tree view, similar to usual operating systems. The right frame presents the content of the course itself, where there is the "Previous/Next" control, a bar with the identification of the student, the title of the topic and the text concerning the topic.

There is an additional resource that is called Tooltip, which has the following feature: when one moves 
the mouse over a concept that needs greater explanation, the Tooltip creates a layer on the text with an explanation regarding the concept.

As PHP is an interpreted language, its programming generates scripts instead of binary files, which are part of compiled languages. The PHP scripts used to create the system are basically used for insertion and alteration of MySQL database lines, which work in the Federal University of Uberlândia servers, as well as the PHP interpreter, which is installed in the same servers.

The functionalities supplied by the PHP scripts for the Pulverizar program are as follows: insert student in database, register the moment of each student entry in the system, as well as register his/her exit, calculate the average of marks obtained by the student during the course and the percentage on course conclusion, keep the last page visited by the student, so that when he/she accesses the system again, he/she can restart from where he/she left off, correct the evaluations of each module and save the mark of each evaluation in the database, allow the student to re-do a certain evaluation if the grade is lower than $60 \%$, register the student's opinion in the opinion questionnaire, manage the system in an administrative area, list all students registered in the system, as well as all their data, and list the results of the opinion questionnaire.

Other features supplied by the system are framed in the "special effects" category. They have no interference on the system data, but make it more attractive to the eyes and facilitate the user's interaction with the system. For Pulverizar, the "special effects" were created using Javascript. The functionalities of this category are: cause the glass box effect on system's presentation screen, show the movement of tree view control, organize data using table columns, such as that of a Portuguese-English glossary, alternatively add a paragraph in bold to the text and the following in normal script, and validate the evaluation form, not accepting that any question goes unanswered.

The course is divided into modules, and the student has the option of taking the course in the order he prefers. Each module corresponds to one level in the tree view control, and the subjects of each module correspond to the sublevels. The content of the course is presented in the following way: Module 1 - Basic con- cepts; Module 2 - Factors that affect application; Module 3 - Equipments; Module 4 - Spraying nozzles; Module 5 - Sprayer calibration; Module 6 - Aerial application; Module 7 - Chemigation; Module 8 - Physicalchemical properties; Module 9 - Formulations; Module 10 - Adjuvants; Module 11 - Water quality; Module 12 - Adequate use of pesticides; Glossary Portuguese/ English; Bibliography; and opinion questionnaire.

There is an evaluation at the end of each module with multiple choice questions. Before the student begins the evaluation, the objectives proposed at the beginning of the module are represented, so that the student knows if he/she is prepared to take the exam. The student can make the module evaluation whenever he wants. If the marks obtained are lower than $60 \%$, he/ she has the option of re-taking the test.

There is also a special module called "Glossary of Technical Terms" in Portuguese/English. The intention was to list the main technical terms concerning pesticide application technology that are not found in common dictionaries. This is to facilitate the reading of international articles in the area by graduate and postgraduate students.

The bibliography consulted in the elaboration of the course is also at the same level of the modules, in the control tree view.

According to Hrastinski (2008), participation is an intrinsic characteristic of teaching. The key to e-Learning systems as a teaching activity and online learning is to multiply and facilitate participation forms. In this way a forum has been incorporated to the system, which is nothing more than an independent and gratuitous subsystem that has been developed externally. This component is used in many internet sites for the most varied purposes. One of these is looking for a ready-made tool in order to not losing focus on constructing the main system.

The idea is that the student, whenever he/she has doubts during the course, can attend forums, and all involved can generate a public discussion around the topic. Teachers will only interfere in the discussion if it strays from the initial theme or if there is still doubt.

An opinion questionnaire is presented upon the conclusion of the course. The student can give only one answer; the questionnaire is anonymous and can only 
be sent if all the questions are answered.

The questionnaire was divided into five sections (System Environment, operation/interactivity, pedagogic conception, relevance and suggestions/comments), with a total of 25 questions, 22 being objective questions, which the student numbers from 1 to 5 , according to the adaptation intensity of the question, and 3 discursive questions, in which the student writes opinions and suggestions.

During the initial tests of the system with its target public, the information that was received at the beginning of the process was used to correct editorial errors and operational difficulties. Later, 100 opinion questionnaires were set to be performed, so that the data regarding the program evaluation could be organized, computed and submitted for a descriptive statistical analysis. This was done through a study concerning the frequency of answers obtained.

Once the construction of the system and correction of initial errors had been made, the system became available on the World Wide Web by lodging in the site of the Federal University of Uberlândia. It was tested in graduation and masters degree disciplines in Agronomy at the Federal University of Uberlândia, always with the presence of a learning contract, which, as mentioned by Pereira et al. (2005), is one of the characteristics of e-Learning.

The course was applied to graduation groups in the area of "Agricultural Machines" and "Applied Mechanics" and to post graduation students of the "Pesticide Application Technology" discipline.

The system became public to people from all over Brazil. This was done through lists of contacts and social networks regarding agronomy. In this way, as the students of the Federal University of Uberlândia, people from all over the country enrolled in the system.

\section{RESULTS AND DISCUSSION}

The content of the Pulverizar system was lodged in the servers of the Federal University of Uberlândia under the address http://www.pulverizar.iciag.ufu.br. The system was shown to be robust and with good coverage of the subjects regarding application technology.

The number of users registered in the system until $15^{\text {th }}$ September, 2008, was 210 . The user profile was composed of both sexes, $26 \%$ being female and $74 \%$ male, representing 10 Brazilian States. Minas Gerais accounts for $86 \%$. With regards to educational levels, $71 \%$ of the users were attending higher education, $11 \%$ had finished university, 3\% had secondary technical degrees, 9\% were attending post-graduate courses, and $6 \%$ had finished post graduation. Among them, $88 \%$ were in the 17 to 29 age group.

Considering 210 users of the system, $41 \%$ did not complete $100 \%$ of the course. This also corresponds to the number of non-student users who were enrolled in graduation and post graduation disciplines involved in the program evaluation. This demonstrates the importance of having a learning contract (Pereira et al. 2005).

The percentage of registered users who had answered the final evaluation questionnaire of the system by $15^{\text {th }}$ September, 2008 , was $52 \%$. This result fulfilled the initial objective proposed, which was to have 100 answered questionnaires.

With regards to the students who answered the questionnaire, $85.32 \%$ scored 4 and 5 to the system (Table I) and, thus, considered it pleasant to use. This shows that a higher level of programming, with more lively resources obtained through Javascript, is necessary to win over the student.

When questioned about the simplicity of the system, $50.46 \%$ of the students scored 5 (Table I). With regards to the system facilitating the student's study task, $65.14 \%$ scored 5 to the system (Table I), confirming that mentioned by Almeida (2003), who states the efficiency of distance education compared to the traditional study methods. This is due to the fact that the system makes the learning task more active.

As to the graphic quality of the system, $75.22 \%$ of the students scored between 4 and 5 (Table II). This is directly linked to the first question of the questionnaire, reinforcing the point that it is necessary to have a higher level of programming to improve the experience with the system.

On technical problems regarding the system, $65.14 \%$ of the students scored 5 (Table II), showing that the system worked appropriately. The main problems reported concerned the incompatibility of some navigators and the fact that the university servers were turned off on some weekends without prior notice. 
TABLE I

Distribution of answers to questions on the environment concerning the Pulverizar system based on marks given to each item.

\begin{tabular}{|c|c|c|c|c|c|c|}
\hline \multirow{2}{*}{ Question } & \multicolumn{5}{|c|}{ Answer (\%) } & \multirow{2}{*}{ Total } \\
\hline & 1 & 2 & 3 & 4 & 5 & \\
\hline $\begin{array}{l}\text { On the whole, can the system be } \\
\text { considered...? (Disagreeable/Agreeable) }\end{array}$ & 0.92 & 0.92 & 12.84 & 44.04 & 41.28 & 100.00 \\
\hline $\begin{array}{l}\text { Is the system self explanatory? } \\
\text { (Complicated/Simple) }\end{array}$ & 12.84 & 0.92 & 9.17 & 26.61 & 50.46 & 100.00 \\
\hline $\begin{array}{l}\text { Does the program help the students to } \\
\text { study the task? (Makes it more } \\
\text { Difficult/Easier) }\end{array}$ & 0.92 & 0.00 & 7.34 & 26.61 & 65.14 & 100.00 \\
\hline \multicolumn{7}{|c|}{$\begin{array}{l}\text { TABLE II } \\
\text { Distribution of answers to questions about the operation and interactivity of the Pulverizar } \\
\text { system according to scores given to each item. }\end{array}$} \\
\hline \multirow{2}{*}{ Question } & \multicolumn{5}{|c|}{ Answer (\%) } & \multirow{2}{*}{ Total } \\
\hline & 1 & 2 & 3 & 4 & 5 & \\
\hline $\begin{array}{l}\text { Esthetics and graphic quality: } \\
\text { (Regular/Excellent) }\end{array}$ & 2.75 & 1.83 & 20.18 & 37.61 & 37.61 & 100.00 \\
\hline $\begin{array}{l}\text { Was there a technical problem during } \\
\text { the use? (Yes/No) }\end{array}$ & 13.76 & 5.50 & 9.17 & 6.42 & 65.14 & 100.00 \\
\hline $\begin{array}{l}\text { Formatting of windows and links: } \\
\text { (Regular/Excellent) }\end{array}$ & 2.75 & 2.75 & 16.51 & 33.03 & 44.95 & 100.00 \\
\hline User friendly: (Difficult/Easy) & 0.92 & 0.92 & 6.42 & 23.85 & 67.89 & 100.00 \\
\hline
\end{tabular}

As to the formatting of windows and links, $49.54 \%$ of the students scored between 3 and 4 to the system (Table II), showing that the layout needs to have a deeper study carried out before being built. In computer programming companies these tasks are divided into teams: drawing, programming and testing, among others.

With regards to user friendliness, $67.89 \%$ of the students considered the system as user friendly (Table II). It is also important to point out that, in spite of living in an age in which computer science is natural, many people still do not have contact with other systems apart from the more common text editors.

On the treatment given to the topic "Pesticide Application Technology" $65.14 \%$ of the students scored 5 to the system (Table III), considering that it fulfills its objective of bringing the student to reflect on the conceptions presented.

As to the visual resources, $60.55 \%$ scored 5 to the system (Table III). This shows once more the importance of investing in programming resources that can render the system more interactive.

The aims for each module were scored 5 by $55.96 \%$ of the students (Table III). The fact that they were brief and clear probably contributed to the result that was presented.

On questions concerning the forum, a negative result was already expected because the students did not make use of this resource. The cause may probably be connected to the fact that the use of the forum, entry of doubts and answers to other students' enquiries had not been specified in the learning contract.

The sequence given to the subject "material" of the course was scored 5 from $59.63 \%$ of the students (Table III). This demonstrates that the order is adequate, in spite of the student being free to study the topics without a specific order. With regards to the auxiliary learning system, $58.72 \%$ of the students evaluated the program scoring 5 (Table III). This reinforces that e-Learning is an answer for distance education to the modern educational paradigm.

As to the system having caught the students' at- 
TABLE III

Distribution of answers to questions on the pedagogical conception of the Pulverizar system according to the scores given to each item.

\begin{tabular}{|c|c|c|c|c|c|c|}
\hline \multirow{2}{*}{ Question } & \multicolumn{5}{|c|}{ Answer (\%) } & \multirow{2}{*}{ Total } \\
\hline & 1 & 2 & 3 & 4 & 5 & \\
\hline $\begin{array}{l}\text { Does the treatment given to the subject } \\
\text { stimulate the student to reflect on the } \\
\text { notions presented? (No/Yes) }\end{array}$ & 2.75 & 0.00 & 6.42 & 25.69 & 65.14 & 100.00 \\
\hline $\begin{array}{l}\text { Do the format and visual resources used } \\
\text { in the system...? (Hinder/Help) }\end{array}$ & 0.92 & 0.00 & 11.93 & 26.61 & 60.55 & 100.00 \\
\hline $\begin{array}{l}\text { Is the exposition of the objectives of } \\
\text { each module...? (Obscure/Clear) }\end{array}$ & 0.92 & 0.00 & 11.01 & 32.11 & 55.96 & 100.00 \\
\hline $\begin{array}{l}\text { Were the objectives of each } \\
\text { module reached? (No/Yes) }\end{array}$ & 1.83 & 0.00 & 9.17 & 35.78 & 53.21 & 100.00 \\
\hline $\begin{array}{l}\text { Did you consult the forum when } \\
\text { you had doubts? (Few times/Various times) }\end{array}$ & 58.72 & 9.17 & 10.09 & 10.09 & 11.93 & 100.00 \\
\hline $\begin{array}{l}\text { Did reading the doubts of other } \\
\text { students in the forum help you to } \\
\text { solve your own? (No/Yes) }\end{array}$ & 53.21 & 12.84 & 12.84 & 6.42 & 14.68 & 100.00 \\
\hline $\begin{array}{l}\text { Is the sequence of topics } \\
\text { adequate? (No/Yes) }\end{array}$ & 1.83 & 0.92 & 11.01 & 26.61 & 59.63 & 100.00 \\
\hline $\begin{array}{l}\text { Does the use of the system help in } \\
\text { learning when compared with } \\
\text { traditional classes? (a Little/a Lot) }\end{array}$ & 3.67 & 1.83 & 10.09 & 25.69 & 58.72 & 100.00 \\
\hline $\begin{array}{l}\text { Did the use of the system catch } \\
\text { your attention? (a Little/a Lot) }\end{array}$ & 5.50 & 2.75 & 20.18 & 31.19 & 40.37 & 100.00 \\
\hline $\begin{array}{l}\text { In your opinion, can the system be used } \\
\text { by any professional or student from the } \\
\text { area of Agricultural Sciences? (No/Yes) }\end{array}$ & 2.75 & 0.92 & 5.50 & 21.10 & 69.72 & 100.00 \\
\hline
\end{tabular}

tention, $40.37 \%$ of the students scored 5 , and $31.19 \%$ scored 4 . The efficiency of the system concerning this requirement is due to the possibility of the student being able to complete the course with freedom of schedule and place. Also, according to the replies, the system can be used by any professional or student from the area of Agrarian Sciences.

Regarding the course satisfaction, $48.62 \%$ of the students scored 5 (Table IV), showing that their expectations corresponded to those presented by the system. Franco et al. (2003) implanted a teacher training system in Campinas University (Brazil), and their evaluation led to the conclusion that the main advantages of distance education are to encourage the autonomous learning and offer more time for reading and discussing the use of computer resources.

Concerning the applicability of the course, $55.96 \%$ scored 5 to the system (Table IV). The revision made on the literature for the course is up to date and inclusive, within the limits of the course. However, it is still a theoretical course and, because of this, one realizes the importance of reconciling it with the traditional study methods, in which the teacher can expose his/her experiences and the students have access to practical classes.

Regarding the level of deepening the knowledge on the subject, $50.46 \%$ of the students scored 4 to the system (Table IV). This is because it is not geared exclusively to post-graduate students. The general evaluation of the course shows that the system was approved by $53.21 \%$ of the students who scored 5 (Table IV).

Suggestions coming from the students demonstrated that the evolution of the system will result in the incorporation of more interactivity resources, which are more accessible and available every day. A great 
TABLE IV

Distribution of answers to questions about the relevance of Pulverizar system according to scores given to each item.

\begin{tabular}{l|c|c|c|c|c|c}
\hline \multirow{2}{*}{ Question } & \multicolumn{5}{c|}{ Answer (\%) } & \multirow{2}{*}{ Total } \\
\cline { 2 - 6 } & 1 & 2 & 3 & 4 & 5 & \\
\hline $\begin{array}{l}\text { Satisfaction on expectations in relation to } \\
\text { course program: (Not satisfied/Satisfied) }\end{array}$ & 13.76 & 2.75 & 8.26 & 26.61 & 48.62 & 100.00 \\
\hline $\begin{array}{l}\text { Applicability (in your company/ } \\
\text { organization/day to day): } \\
\text { (Not Applicable/Largely applicable) }\end{array}$ & 0.92 & 3.67 & 7.34 & 32.11 & 55.96 & 100.00 \\
\hline $\begin{array}{l}\text { Approach to theme (level of understanding): } \\
\text { (Superficial/Profound) }\end{array}$ & 0.92 & 3.67 & 9.17 & 50.46 & 35.78 & 100.00 \\
\hline $\begin{array}{l}\text { Updating of content: } \\
\text { (Out of date/Up to date) }\end{array}$ & 0.92 & 0.92 & 6.42 & 23.85 & 67.89 & 100.00 \\
\hline $\begin{array}{l}\text { General evaluation of the course: } \\
\text { (Bad/Excellent) }\end{array}$ & 0.92 & 0.00 & 5.50 & 40.37 & 53.21 & 100.00 \\
\hline
\end{tabular}

advantage of systems such as Pulverizar is its dynamism. The alterations and increments are easy to be accomplished, practically without costs.

\section{CONCLUSIONS}

The program developed as Pulverizar performs its objectives as an e-Learning system. It shows itself to be simple, robust and practical as a complement to traditional teaching for professional formation in the area of Agrarian Sciences with regards to pesticide application technology.

The system makes access available for all interested professionals, at any time, place and at low cost for the student, thus fulfilling an important social role in the development of more sustainable agriculture.

The domain of technology regarding pesticide application, considering those involved in agricultural production, can be increased through the Pulverizar program.

\section{ACKNOWLEDGMENTS}

The authors would like to thank Coordenação de Aperfeiçoamento de Pessoal de Nível Superior (CAPES), Fundação de Amparo à Pesquisa do Estado de Minas Gerais (FAPEMIG), and Conselho Nacional de Desenvolvimento Científico e Tecnológico (CNPq) for financial support.

\section{RESUMO}

O ensino à distância apresenta grande potencial para minorar os problemas ocorridos no campo na área de tecnologia de aplicação de agroquímicos. Dessa forma, diante da escassez de material instrucional na área de tecnologia de aplicação de agroquímicos em Português e do crescimento elevado da educação à distância, o objetivo deste trabalho foi desenvolver e avaliar um programa computacional para o ensino à distância da parte teórica de tecnologia de aplicação de agroquímicos, utilizando as ferramentas de tecnologia da informação. Os módulos que compuseram o curso, intitulado Pulverizar, foram: (1) Conceitos básicos, (2) Fatores que afetam a aplicação, (3) Equipamentos, (4) Pontas de pulverização, (5) Calibração de pulverizadores, (6) Aplicação aérea, (7) Quimigação, (8) Propriedades físico-químicas, (9) Formulações, (10) Adjuvantes, (11) Qualidade da água e (12) Uso adequado de agroquímicos. O programa desenvolvido foi disponibilizado ao público no dia 1 de julho de 2008, hospedado no sítio www.pulverizar.iciag.ufu.br, mostrando-se simples, robusto e prático no complemento ao ensino tradicional para a formação de profissionais da área de Ciências Agrárias. O domínio da tecnologia de aplicação de agroquímicos por parte das pessoas envolvidas na produção agrícola pode ser incrementado por meio do programa Pulverizar, que teve boa aceitação em seu processo de avaliação inicial.

Palavras-chave: ensino à distância, aplicação de agrotóxicos, pulverização, estratégias de ensino/aprendizagem. 


\section{REFERENCES}

AlmeIdA MEB. 2003. Educação a distância na internet: abordagens e contribuições dos ambientes digitais de aprendizagem. Educ Pesqui 29: 327-340.

Cho CA, Chong G, Wolf T, Hogg T, Johson E And BANNIZA S. 2008. The effect of spray quality on ascochyta blight control in chickpea. Crop Protec 27: 700709 .

CUNHA JPAR. 2008. Simulação da deriva de agrotóxicos em diferentes condições de pulverização. Cienc Agrotec 32: $1616-1621$

FRANCO MA, CORDEIRo LM AND CASTILlo RAF. 2003. $\mathrm{O}$ ambiente virtual de aprendizagem e sua incorporação na Unicamp. Educ Pesqui 29: 341-353.

Ghedine T, Testa MG and Freitas HMR. 2006. Compreendendo as iniciativas de educação a distância via internet: estudo de caso em duas grandes empresas no Brasil. Rev Adm Pública 40: 427-455.

GIL Y AND SINFORT C. 2005. Emission of pesticides to the air during sprayer application: a bibliographic review. Atmospheric Environ 39: 5183-5193.

HRASTINSKI S. 2008. What is online learner participation? A literature review. Computers \& Educ 51: 1755-1765.
KIM W AND SHIH TK. 2003. Distance education: the status and challenges. J Object Technology 2: 35-43.

KUTCHER HR AND WOLF TM. 2006. Low-drift fungicide application technology for sclerotinia stem rot control in canola. Crop Protec 25: 640-646.

Pereira A, Mendes AQ, Morgado L and Aires LL. 2005. Um modelo pedagógico para o ensino pós-graduado em regime de e-learning. In: International Conference of Information and Communication Technologies in Education, 4, Braga, Portugal. Anais... Braga: Ipleria, p. 303-318.

REEVES TC. 2008. Evaluation of the design and development of IT tools in education. In: VOOGT J AND KNEZEK G (Eds), International Handbook of Information Technology in Primary and Secondary Education, New York: Springer, p. 1037-1051.

Scudeler F, Raetano CG, Araujo D and Bauer FC. 2004. Cobertura da pulverização e maturação de frutos do cafeeiro com ethephon em diferentes condições operacionais. Bragantia 63: 129-139. 